\title{
DEVELOPMENT OF WASTE COLLECTION SERVICES ON RURAL TERRITORY FROM NEAMT COUNTY
}

\author{
Mihai Florin - Constantin *, Apostol Liviu \\ * Alexandru Ioan Cuza “ University, Faculty of Geography and Geology ,Carol I \\ Avenue .nr 20 A, 700505,Iasi,Romania, email : mihai.florin86@yahoo.com
}

\begin{abstract}
This paper analyzes the expansion of sanitation services in rural areas after the closure and rehabilitation of rural dumpistes having as deadline July 16, 2009. Following this period local authorities are forced to collect and dispose the waste generated in urban landfills from proximity until the transfer stations will be operational. Most of the rural population has no access to waste collection services, waste generated and uncollected are uncontrolled disposed polluting the local environment. Development of sanitation services is a basic condition for an efficient implementation of integrated waste management system at county level.
\end{abstract}

Keywords: sanitation services, dumpistes, waste management,rural areas

\section{INTRODUCTION}

The improper sanitation services lead to illegal dumping of waste from various geographical regions (Chen,2010;Ichinose and Yamamoto,2011; Apostol and Mihai,2011).Sanitation services are poorly-developed and partially covering rural regions in Romania (Apostol and Mihai,2012). Waste generated and uncollected from urban and rural areas are uncontrolled disposed polluting the local environment ( Mihai et al., 2011) In rural areas were done very few studies on waste management until 1990 , the literature does not have conclusive data (Bularda e al.,1992).Also,waste generated from rural localities are not subject to waste statistics in Romania, because they are difficult to follow in the context of limited acces to sanitation services.(Bold and Maracineanu,2003,Bold, 2006)

Following 1990, governmental programs have neglected the issue of waste management infrastructure regarding the collection and recycling (Vadineanu,1998). Waste issue from Romania's rural territory is not governed by the authorities (Wehry and Orlescu,2000). The "Agenda 2000" document which has been analyzed Romania's EU accession outlines the lack of a waste management system (Nicoara,2009). Environmental policies on waste management has took the scale only in the context of Romania's EU accession.

Frequently,bad practices on waste managemnet lead to complex pollution(Ungureanu,2005).Agricultural production potential of large areas of soil is blocked by covering areas with mining dumps, landfills or animal 
manure (Ungureanu et al., 2003). Scarcity of data on waste management from rural ares makes difficult a pertinent analysis at regional or local level.

\section{MATERIALS AND METHODS}

Analysis of the territorial extension of waste collection services from rural areas was performed using thematic cartography. There were consulted the annual reports of EPAs Neamt,county waste management plans and data supplied by the Environmental Guard, County Commissariat or local authorities from rural areas.Also based on thematic maps a comparative analysis is performed between the first regional approach of waste management at county level described in territorual planning from 1996 and the integrated system of solid waste management that will be implemented. Field observations in the period 2009-2011 are intended to highlight the positive and negative changes of waste management in rural areas.

\section{RESULTS AND DISCUSSION}

During 2000 -2003 only Roznov and Săvineşti communes had their own sanitation services, waste collected being disposed in open dumps ( eg. municipal and non-hazardauous industrial landfill from Savinesti village) or on floodplain of Bistrița river. Although in 2004 Roznov was declared city, the population did not have acces to sanitation services in the period 20042010 ! In 2005, the population served by sanitation services is $38 \%$ of the total number of inhabitants in the county, the urban coverage rate is $79 \%$ while in rural areas only 12\% (APM,2006). Waste collection services of urban areas have expanded their activity in the rural ares from neighborhood including 8 communes in 2006. (PJGD, 2008) However, in 2007 , the share of population served with sanitation services in urban areas was $62.70 \%$ and only $9.08 \%$ in rural areas. Limited access of rural population to sanitation services has led to uncontrolled disposal of waste. Local authorities have chosen some sites where the waste could be disposed. Sanitation services were not well organized and waste collection did not occur regularly. Often rivers are assigned the position of collector for various types of waste (Mac, 2003). Rivers in the proximity of human settlements from mountain or subcarpathian regions are most vulnerable to waste pollution because the lacking of sanitation services. Following July 16, 2009 under EU rules, municipalities are obliged to close the dumpsites on their range and to sign contracts with waste operators or to provide own services.

Waste collected should be transported to urban landfills (Roman or Târgu Neamt) until the transfer stations will become operational (fig.1) This explains the more communes number served by waste collection service in 
2009 compared to 2006. It is noted that most communes benefit from these services after July 16, 2009 and in general only a fraction of the population is served

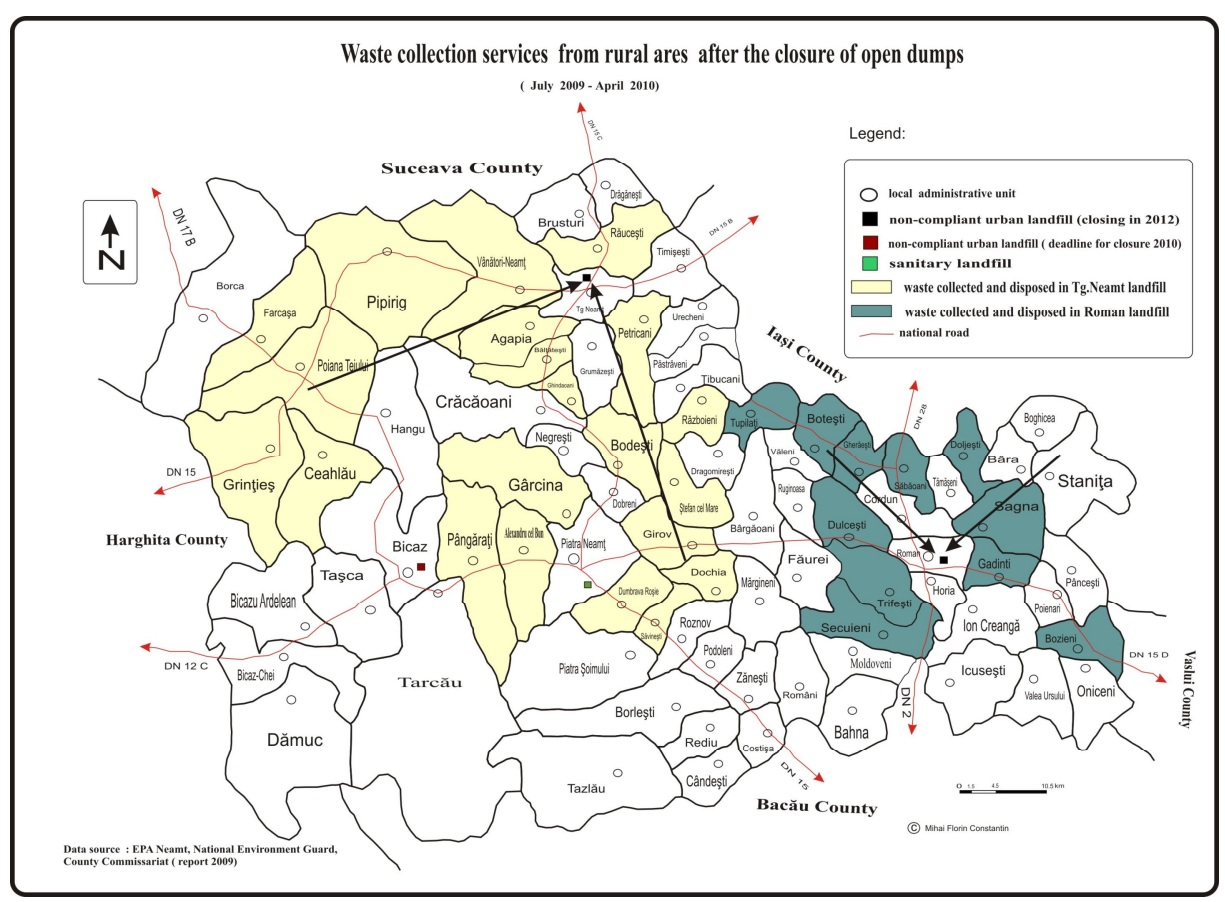

Fig.1The expansion of waste collection services on rural territory

In some communities (eg Agapia.Bălțăteşti etc) although lacking of waste containers, local authorities provide waste collection from households monthly or weekly in bags, being transported to Târgu Neamț landfill.

Sanitary landfill from Piatra Neamt built with ISPA funds does not allow the landfilling of the waste collected from rural areas, these site serving only territorial administrative of Piatra Neamț city (includind 3 rural communities such as Doamna,Văleni and Vânători). In this context, waste collected from peri-urban communes (Dumbrava Rosie,Girov,Gârcina, Alexandru cel Bun) are transported to non-compliant landfill of Târgu Neamt city. Thus, the cost of sanitation services is higher due to transport.

Mixed waste collection prevails,separate collection is rarely seen and generally the only plastic is collected. However,in 2011 separate collection containers were installed for plastics, paper / cardboard, biodegradable and residual waste in Piatra Soimului and Borlesti communes (fig 2). 


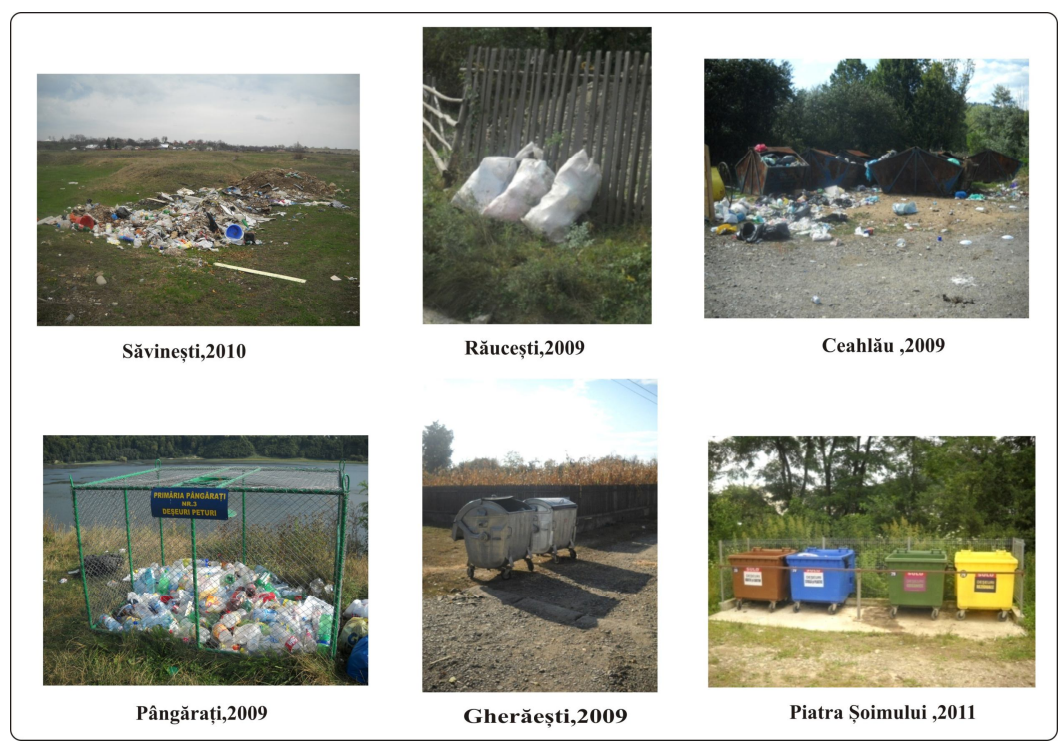

Fig.2. Illegal dumping ( Săvinești village) and waste collection services from various communes

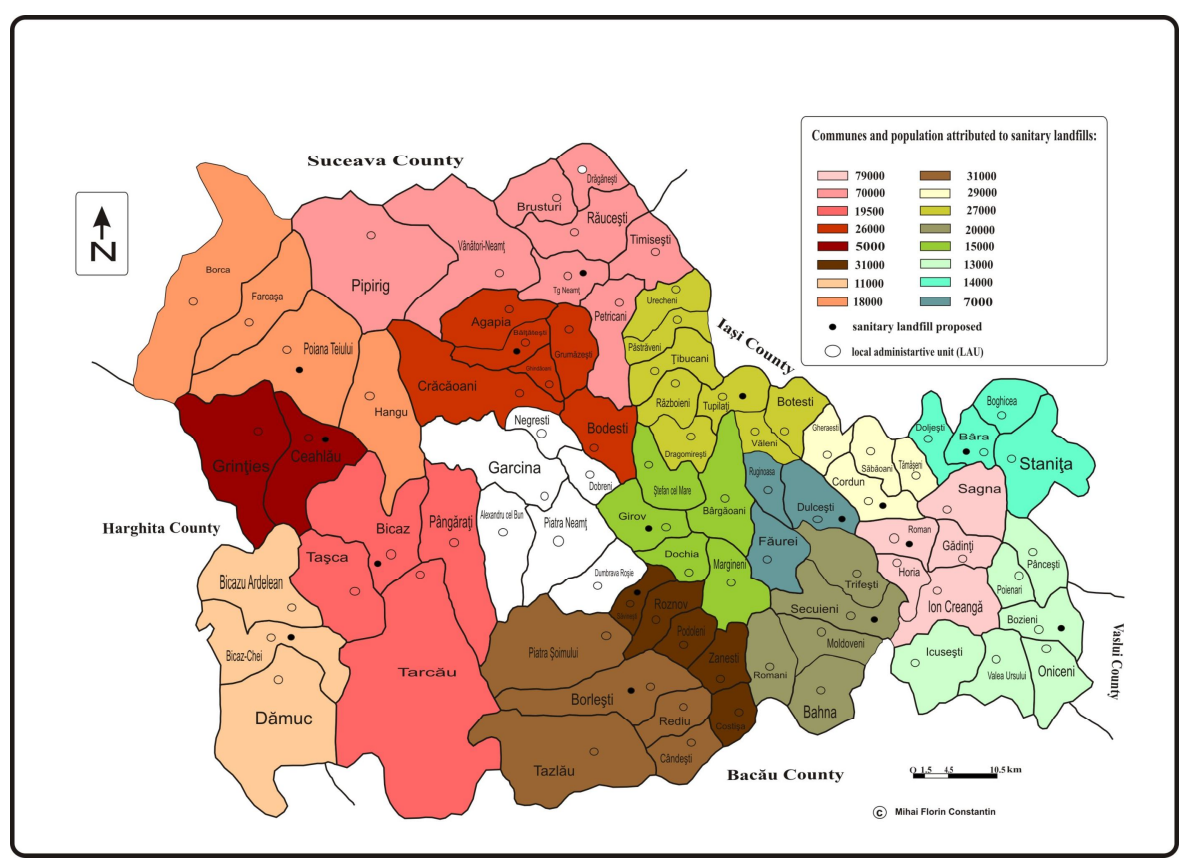

Fig.2 Proposals for sanitary landfills in territorial planning of Neamt County from 1996

Territorial Planning of Neamţ County (PATJ) was established in 1996, proposing facilities for water supply systems, sewerage systems and landfills (PJGD,2003).This plan (fig.2) presented for the first time a regional approach of waste management issue but did not include all rural localities from county. 
Another deficiency of this proposal is the small number of people subordinated to a sanitary landfill - between 5000 - 31.00 people (except the Roman and Târgu Neamţ cities), which does not ensure the economic viability of these waste management systems. The integrated solid waste management system provides the construction of three transfer stations equipped for sorting and separate collection of waste. These facilities will be located in cities or in peripheral communes (Târgu Neamţ, Roznov and Cordun commune near Roman city) and will receive the waste collected from rural localities(fig.3) Waste that can not be recovered will be disposed of in sanitary landfill located in the commune Girov. It is noted that sanitary landfill from Piatra Neamt city will be operational until 2017, following this term the waste will be disposed in Girov landfill.

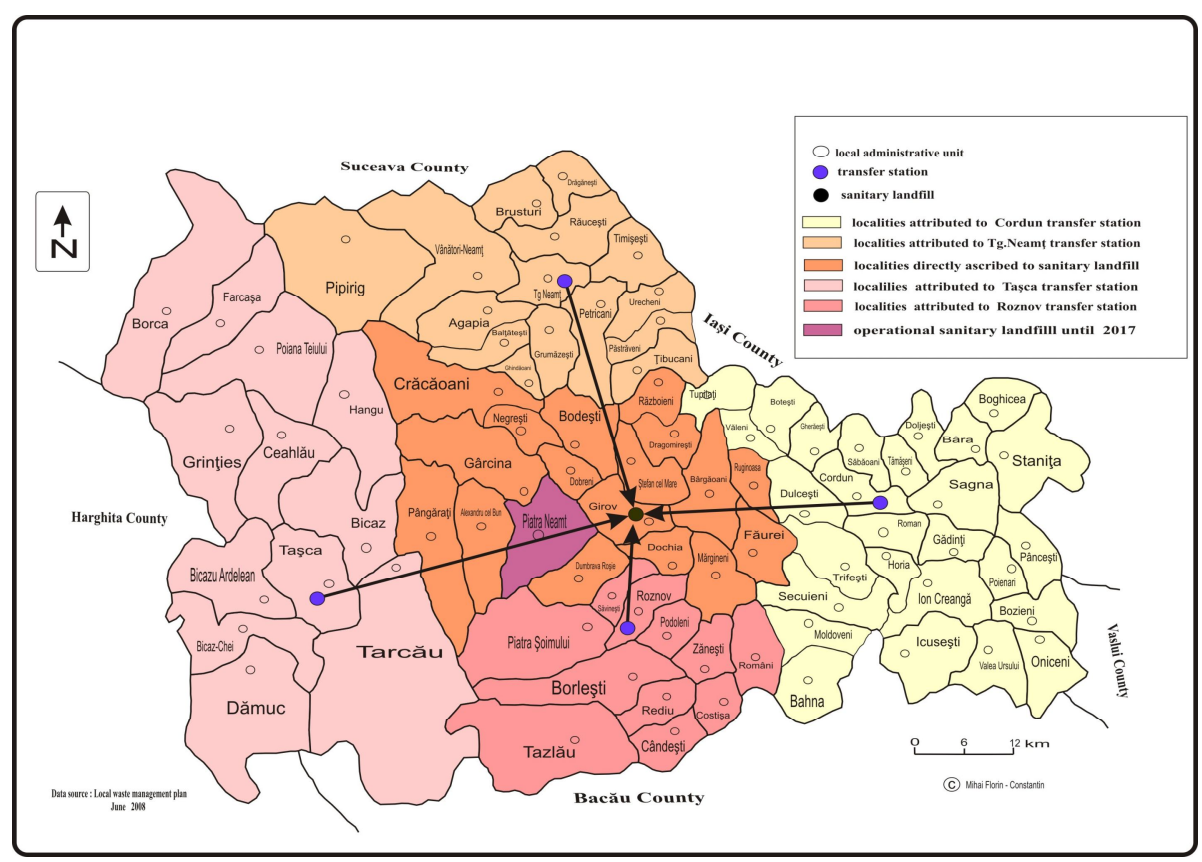

Fig.3 The future integrated solid waste management system at county level

\section{CONCLUSIONS}

Partially access of the rural population to waste collection services lead to illegal dumping of household waste generated and uncolleted polluting the environment in the proximity of human settlements.Poor solid waste management facilities encourages the bad practices such as open dumping or uncontrolled disposal on rivers banks, local roadsides or forest areas.Sanitation services on rural territory is emerging under the pressure of EU regulations. 


\section{Acknowledgements}

This work was supported by the the European Social Fund in Romania, under the responsibility of the Managing Authority for the Sectoral Operational Programme for Human Resources Development 2007-2013 [grant POSDRU/CPP 107/DMI 1.5/S/78342].

\section{REFERENCES}

1.Apostol L., Mihai F.C., 2012 , Rural waste management : challenges and issues in Romania, Present Environement and Sustainable Development, 6 (1), in press

2.Apostol, L., Mihai,F.C., (2011). The process of closing down rural landfills Case study : Neamț county. Present Environment and Sustainable Development, 5 (2), 167- 174

3. Bold,O.V., Mărăcineanu ,G.A., 2003,Managementul deşeurilor solide urbane şi industrial,,Edit.Matrix Rom,Bucureşti

4.Bold,O.V ,2006, Gospodarirea resurselor secundare ,Infomin,Deva

5.Bularda,G., Bularda,D.C., Catrinescu,T.,1992, Reziduuri menajere,stradale si industriale,Edit. Tehnica,Bucuresti

6. Chen, C.C., (2010). Spatial inequality in municipal solid waste disposal across regions in developing countries. Int. J. Environ. Sci. Tech., 7 (3), 447-456

7. Ichinose, D., Yamamoto, M.,2011 - On the relationship between the provision of waste management service and illegal dumping, Resource and Energy Economics ,33 ,79-93

8.Lămașanu A., Mihai F.C.,The illegal dumping of waste in forest areas. Evidence from rural territory., In:Integrated Management of Environmental Resources, International Conference, Suceava,Romania, November 4-6th 2011,Proceedings in print

9.Mac,I., 2003, Stiinta mediului,Ed.Europontic, Cluj-Napoca

10.Mihai, F.C., Ghiurca A.,Lamasanu,A.,2011,Estimation of urban waste generated and uncollected in Romania,Analele Universitati Oradea,Fascicula:Protectia Mediului, 17(2),719-724

11.Nicoara, M., ,2009, Legislatie, institutii si politici de mediu ,Tehnopress,Iasi

12. Ungureanu B.I., 2005, Geografia Mediului ,Edit . Universității “Alexandru.Ioan Cuza” ,Iași

13.Ungureanu,B.I.,Muntele,I., Dragu,V.,Gheorghita C.,2003,Geografia Mediului Omul si natura la inceput de mileniu, Institutul European, Iasi

14.Vadineanu,A.,1998,Dezvoltare Durabila Teorie si practica, 1,Ed Universitatii din Bucuresti

15 Wehry A.,Orlescu,M.,(2000) - Reciclarea şi depozitarea ecologică a deşeurilor ,Orizonturi Universitare ,Timişoara,

16. *** APM Neamt Raport anual privind starea factorilor de mediu in judetul Neamt,2006

17.*** Master Plan Judetean - Sistem integrat de gestionare a deşeurilor pentru judetul Neamt , PHARE 2005/017-553.04.03/08.01

18. *** 2008,Plan judetean de gestionare a deseurilor (PJGD) Neamt,

$19 * * * 2004$, Raport la studiul de evaluare a impactului asupra mediului pentru“Sistem integrat pentru managementul deşeurilor solide în municipiul Piatra Neamț"

20.*** 2008,Strategia județeană privind accelerarea dezvoltării serviciilor comunitare de utilităţi publice ,Consiliul Județean Neamţ, 